\title{
TURKISH AND EU SECURITY CULTURES IN PERSPECTIVE: WHY DO WE NEED A HOLISTIC APPROACH TO EUROPEAN SECURITY ${ }^{*}$
}

\section{Münevver CEBECI'**}

\section{Abstract}

This article argues that Turkey and the EU do not have homogenous security cultures; however, their divergences are not greater than those among EU Member States as well as those between the EU and its members. The article pursues this argument by comparing and contrasting Turkey's and the EU's security cultures through the employment of a constructivist ontology and the conceptual frameworks of securitization and desecuritization. It first gives a conceptual overview, defining the terms "security culture", "holistic approach to security" and "European security". Then, it analyses Turkey's and the EU's security cultures separately, looking into their processes of securitization and desecuritization. Finally, it compares these two distinct security cultures with a view to showing that their differences are not that grave to impede the creation of a common European security culture with the involvement of Turkey. This article concludes that there is need for a holistic approach to European security in order to deal with today's multi-layered, cross-border, and complex challenges, and, any arrangement which excludes Turkey in this regard, would render European security incomplete.

Keywords: Turkey, European Union, Security Cultures, Holistic Approach to Security, European Security, Securitization, Desecuritization

$$
\ddot{O} z
$$

Bu makalenin ana argümani, Türkiye ve AB'nin güvenlik kültürlerinin homojen olmadı̆̆ $l ;$ ancak, bu bağlamdaki farklılıkların $A B$ üyesi ülkelerin kendi

\footnotetext{
* This article is a revised and updated version of the author's paper presented the UACES 41st Annual Conference "Exchanging Ideas on Europe 2011", held in Cambridge, on 5-7 September 2011, as part of project no. SOS-D-200611-0229, funded by the Project Office (BAPKO) of Marmara University, Istanbul.

** Associate Professor (PhD), Marmara University, European Union Institute, Istanbul. e-mail: munevvercebeci@marmara.edu.tr
} 
aralarındaki veya $A B$ ile aralarındaki ayrllıklarla hemen hemen ayn olduğudur. Bu makalede Türkiye ve AB'nin güvenlik kültürlerinin karşılaştırılmasl, inşacı bir ontoloji üzerinden ve güvenlikleştirme ve güvenlik-dişllaştırma kavramsal çerçevelerinin uygulanmasıyla yapılmaktadır. Bunun için önce. "güvenlik kültürü", "güvenliğe bütüncül yaklaşım" ve "Avrupa Güvenliği" kavramlart açıklanmaktadır. Makalede, daha sonra, Türkiye ve AB'nin güvenlik kültürleri ayr ayrl ve özellikle güvenlikleştirme ve güvenlik-dışllaştırma süreçlerine referansla irdelenmektedir. Son olarak, bu iki farklı güvenlik kültürünün bir karşılaştırması yapılarak, aradaki farklllıkların, Türkiye'yi de içine alacak ortak bir Avrupa güvenlik kültürünün kurulmasına engel oluşturacak kadar büyük olmadiğının altı çizilmektedir. Makalenin vardiğı sonuç, günümüzün çok katmanl, sinır-aşan ve karmaşık sorunlarını ele almak için Avrupa güvenliğine bütüncül bir yaklaşıma ihtiyaç duyulduğu ve bu bağlamda girişilecek herhangi bir düzenlemenin Türkiye'nin katılımı olmadan eksik kalacăğdır.

Anahtar Kelimeler: Türkiye, Avrupa Birliği, Güvenlik Kültürleri, Güvenliğe Bütüncül Yaklaşım, Avrupa Güvenliği, Güvenlikleştirme, Güvenlik-dışılaştırma

\section{Introduction}

This article aims at comparing and contrasting Turkish and EU security cultures $^{1}$. This is not something new, as it has been done by Cebeci (2004) and Bilgin (2010) in a detailed way before. The major contribution that this article attempts to make is its emphasis on a holistic approach to European security. Its major argument is that although there are divergences in Turkish and EU security cultures; they are not greater than those between the EU and its members furthermore, EU Member States do not also have homogeneous security cultures. Still, if the construction of a European security culture could be possible with such differences among the EU Member States themselves, then it can also be possible with the involvement of Turkey. This study concludes that European security is indivisible, and, thus, the creation of a common European security culture without Turkey's involvement would be incomplete.

Comparing a sui generis international polity such as the EU with a state in terms of their security cultures is not without problems. ${ }^{2}$ Nonetheless, the

\footnotetext{
${ }^{1}$ Some parts of this article are a completely revised and rewritten version of specific parts of the author's PhD thesis (Cebeci, 2004).

${ }^{2}$ Howorth (2007: 180) contends: "The problem is that it cannot be automatically assumed that the two phenomena (national and European strategic culture) are comparable. The EU, to repeat, is not a nation-state and does not behave like one. It behaves differently - both politically and culturally". Although Howorth mostly uses the term "strategic culture" in his book, he also states: "Less frequently, the term 'security culture' is adopted. I prefer this latter term because it is more neutral politically and because I believe it is more appropriate as a label for whatever collective mindset is in fact taking shape
} 
constructivist approach in this study allows for such a comparison due to its focus on cultures and identities rather than purely material structures. Furthermore, it pursues an actor-based analysis rather than a state-centric analysis so that comparing these two entities in a coherent way becomes possible. This article approaches both states and international organizations primarily as constructions and refers to their structural characteristics as such.

The article is organized in such a way to involve a conceptual overview first. Then, it presents an in-depth analysis of norms, culture and identity in Turkey's and the EU's security respectively. Subsequently, it compares and contrasts the EU and Turkey in terms of their security cultures, also tackling the question why there is need for a holistic approach to European security.

\section{Security Culture, Holistic Security, and European Security}

The analysis undertaken in this article builds on the premise that "security interests are defined by actors who respond to cultural factors" (Katzenstein, 1996: 2 ). The article takes security culture as a combination of all the discourses, representations, processes and practices of security which are mainly driven from identity. Therefore, this article is mainly concerned with the ideational factors/meanings which affect the production and implementation of security in Turkey and Europe; i.e., it looks into how threats are defined, and, security is produced/reproduced in these two entities. In this regard, the comparative analysis undertaken here follows a constructivist ontology because it builds on the assumption that "the manner in which the material world shapes and is shaped by human action and interaction depends on dynamic normative and epistemic interpretations of the material world." (Adler, 1997: 322) It asks the questions: "how do Turkey's and the EU's security cultures come into being", "how are their security identities formed?", "how are their securitization/desecuritization processes shaped?" The article also has a slight critical bend as it concludes that there is need for a holistic approach to security.

A holistic approach to security is mainly about going beyond the self/other dichotomy in European security. "Holistic approach to security" as a notion had mostly been used by peace researchers ${ }^{3}$ but has now become frequently used, especially in the EU context. This is also reflected in Javier Solana's statement that the Europeans "have developed a specific culture of security, based on conflict prevention, political management of crises and taking account of the economic and

in the EU." (Howorth, 2007: 178). The term "strategic culture" is employed in this study where necessary, to indicate a particular part of "security culture" with defence connotations.

${ }^{3}$ Terriff et.al. (1999: 73) contends: "By locating peace and war within exploitative and unequal socioeconomic processes this approach [peace studies] depicted peace and security as holistic, multidimensional and indivisible concepts." Emphasis added. 
social root causes of violent action of all kinds" which pertains to "holistic security" (Solana, 2002, emphases added). Zwolski (2012: 992) also regards the EU's holistic approach to security as one which involves "the utilization of the whole range of policy instruments at its disposal in the pursuit of a given policy objective". This refers to an understanding based on the instruments to be employed to provide security. The analysis here takes the preference for and use of various instruments as part of security culture, nevertheless, it does not limit its definition of a holistic approach to security only to those instruments. Rather, it adopts a broader view which also has a geographical bend, as it holds the assumption that security is indivisible, because any conflict in one part of the world carries the risk of spill-over and may be destabilising for the whole world (especially due to the impact of globalisation). Although this article does not take systemic theory as its basis, it would be helpful to have a look at Buzan's (1991: 174-175) statement below to understand the indivisibility of security:

\begin{abstract}
The systemic view emphasizes the indivisible side of security (i.e. interdependence) because it highlights relational patterns and general structures. But it also ties this aspect into the divisible side (i.e. national security) by revealing the link between the individual character of states and the character of the system as a whole. [...] State and system are so closely interconnected that security policies based only on the former must be both irrational and inefficient.
\end{abstract}

After the terrorist attacks of September 11, Buzan (2000: 10) also underlined the possibility of penetration of the zone of conflict into the zone of peace through terrorism, proliferation of weapons of mass destruction, organised crime, immigration, etc. Following such logic, many analysts argue that post-cold war security challenges, especially those which surfaced after September 11 attacks, show the need for a holistic approach to security (e.g., Duke 2002: 169). This involves not only the employment of a wide range of policy tools - from soft measures, such as humanitarian and development aid, to hard ones, such as military crisis management - but also the association of all the actors, which are interdependent in the provision of their security and which are similarly (or even more) affected by any security arrangements that are adopted in this regard.

Another notion which needs clarification at this point is "European security". Tardy (2009:1) and Heisbourg (2009: 211) argue that "European Security" is an "ill-defined" concept. Its meaning differs a great deal according to who attempts to define it. It can be defined in geographical terms as well as according to the "regional security complex theory" (Buzan and Waever, 2003) which mainly focuses on the level of interaction and interwoven security dynamics (cf. Tardy, 2009). This article takes its definition of European security from Heisbourg (2009: 211) who asserts that European security "is an aggregation of actors, threats and policies that is strongly linked with the geographical space that is Europe". In his view: "European security does not in principle equate to the security of the 
European Union. It is a broader concept that reaches out to institutions, states and security interactions that cannot be confined to the EU" (Heisbourg, 2009: 211). A holistic approach to European security, therefore, requires the participation of all European security actors, including Turkey ${ }^{4}$.

\section{Norms, Identity and Culture in Turkey's Security ${ }^{5}$}

Jepperson, Wendt and Katzenstein (1996: 33) argue that "the security environments in which states are embedded are in important part cultural and institutional, rather than material" and that "cultural environments affect not only the incentives for different kinds of state behaviour but also the basic character of states"; i.e. "state identity". This section aims at analysing Turkey's security culture within such a framework. Nevertheless, security culture is not static and takes shape with the changes in the international and domestic contexts, discourses, perceptions as well as with power shifts. Turkey's security culture is also dynamic and it has gone through significant transformation. It is thus analysed under four sub-sections here; namely, the culture of excessive securitization, precarious desecuritization in 2001-2007, gradual over-securitization after 2007, and, Turkey's approach to international security.

\subsection{The Culture of Excessive Securitization ${ }^{6}$}

The founding practice for the Turkish political community was mainly fed with the rhetoric of existential threats to the secularist regime and territorial and national integrity of the country. The predominant security referent had been the state ${ }^{7}$ and the major securitizing actor had traditionally been the military. The military had strict control over Turkish politics and it determined the country's internal and external security policy as well as its foreign policy for a long time. Turkey has, thus, frequently been depicted as a "security-first state" (Cizre, 2000: 5, and, 2003)

\footnotetext{
${ }^{4}$ Note that the author of this article does not agree the Copenhagen School's view of Turkey as an "insulator state" which should be kept out of the EU to perform its role of insulation and provide European security from outside the Union. (see, Buzan and Waever, 2003; Buzan and Diez, 1999).

${ }^{5}$ To recall the title of Jepperson, Wendt and Katzenstein (1996).

6 "Securitization", as a term, is employed in this study to refer to the process of framing a specific issue as a threat and dealing with it through the use of extra-ordinary measures (i.e., treating it within the realm of the state of exception). Securitization starts with a speech act, naming something as a security issue, and continues with the acceptance of an audience (a group of people) which would give the security actor the authority to deal with the said threat, and, it results in the use of extraordinary measures which break the normal political rules of the game (such as limiting fundamental rights and freedoms) (Buzan, Waever and de Wilde, 1998).

${ }^{7}$ Any comparison between a state's security culture and that of an international organisation (such as the EU) would surely point to a difference in terms of the security referent. Nonetheless, the result would be different if one looked at the member states of that institution. It should be noted at this point that the primary security referent in many EU Member States is also the state.
} 
or a "protected democracy" (Cizre, 2000: 4) because of the high level of securitization in the country.

A major factor behind the practices of excessive securitization in the country was that the definition of threats had rather been broad and anything from education to relations with neighbouring countries could be securitized, almost solely with reference to the Turkish state. Furthermore, such security understanding attached equal importance to internal threats and external ones. Especially, fears of secession and the Turkish Armed Forces' fight with the $\mathrm{PKK}^{8}$ in the south-eastern part of the country had a crucial impact on its security understanding. Under such circumstances, the survival of the state had preceded the rights and freedoms of its citizens, leading to severe limitations on fundamental rights and as well as on minority rights.

Arguments naming the country as "a special case" - on the basis of security had frequently been used to justify Turkey's problems in consolidating its democracy ${ }^{9}$. Such arguments maintained that the threats surrounding the country (due to its "unique" geostrategic position) - coupled with the specific nature of its internal dynamics (including the threats of secession, religious fundamentalism and terrorism) - had rendered its democratization rather delicate ${ }^{10}$. It was through this logic that Turkey's democracy had been evaluated in the light of the conditions specific to the country. Pluralism had been regarded by secular-nationalist political and military elites as a potential threat to the national unity and territorial integrity of Turkey. Securitization on such lines had usually caused a recurrence of authoritarian practices on the part of the state; in the form of restrictions on fundamental rights and freedoms - especially freedom of peaceful assembly, thought, and expression - and minority rights. Furthermore, the military's predominance in Turkish politics had also led to attempts to find military solutions to problems with societal, economic and cultural root causes. This military approach was especially prevalent in the country's fight against the PKK.

\footnotetext{
${ }^{8}$ The Kurdistan Workers' Party, a group which has been in the EU's list of terrorist organisations since 2002. European Commission (2002a).

${ }^{9}$ Aydınlı and Waxman (2001: 385) quote Ecevit stating: "[...] demands for further democracy are nice but Turkey's special geopolitical conditions require a special type of democracy". This quotation in Aydınlı and Waxman is made from Hürriyet, 07.09.1999 (the title of the article n/a).

${ }^{10}$ Note Ecevit's statement: "In Turkey, the [Turkish Armed Forces] has a special position. This position is caused by Turkey's specificity. Turkey is located in a critical region in terms of security when compared to Western European countries. This is why internal security and external security become inseparable. Therefore, European countries are not in a position to be taken as an example. Because Turkey has a unique [sui generis], very sensitive geopolitical position. Meanwhile, the issue of the National Security Council (NSC) is sometimes put on the agenda. If the NSC had not existed, it would have to be established." Hürriyet (2000).
} 
Turkey's foreign policy had also been shaped through the meaning attached to its security. Its interests, discourses, preferences and foreign policy practice had all been defined according to this security understanding which was based on "a fear of abandonment and a fear of loss of territory" as well as "an assumption of geographical determinism" (Bilgin, 2005: 183) ${ }^{11}$ - the rhetoric of Turkey's specific geopolitical conditions. The "fear of abandonment and a fear of loss of territory" mainly pertain to the Sévres syndrome ${ }^{12}$ which also underlies Turkey's quest for becoming a member of the EU. This quest can also be read as a continuation of the country's "defensive Westernization" which started with the decline of the Ottoman Empire (as argued by Bilgin, 2005), when the Ottomans chose Westernisation as a way to avoid invasion by Europeans. The main logic behind such Westernization was not only technical, aiming at the modernization of the army. It also had an identity aspect, because it was an attempt to end the European perceptions of the Ottoman Empire as the "other" of Europe, which, they thought, would free the empire of hostile acts/interventions by the West. On the other hand, just as such fears led to efforts to preserve the Ottoman Empire's borders through passive policies and defensive Westernisation, the Turkish Republic had also opted for preserving the status quo in its foreign policy and shaped its domestic politics in such a way to avoid any loss of territory and national unity.

\subsection{Precarious Desecuritization in 2001-2007}

Turkey's aim to become a member of the EU, and, its attempts at the fulfilment of the EU's Copenhagen criteria have started a process of gradual desecuritization $^{13}$ in the country. In the period between $1999^{14}$ and 2005, Turkey

\footnotetext{
${ }^{11}$ Bilgin borrows the phrase "a fear of abandonment and a fear of loss of territory" from N.B. Criss and A.L. Karaosmanoğlu, "Explaining Turkey's Alignment with NATO: Realism and Culturalism", Unpublished paper, (n.d.). Bilgin (2005: 183-184) contends that although the "fear of abandonment and fear of loss of territory" is "often associated with the Sévres Treaty, its origins arguably lie deep in Ottoman history".

12 "Sévres syndrome" can be defined as the fear caused in Turkey because of the experience of invasion by European powers (the French, English, Italians, Russians and Greeks) after World War I and the signing of the subsequent Treaty of Sévres, which divided the Turkish soil amongst them and stipulated the possible establishment of Armenian and Kurdish states on it. The Treaty of Sévres became void because Turkey won its War of National Independence against the invading European armies, and, the Treaty of Lausanne was signed on July 24, 1923 which led to the establishment of the Republic of Turkey on October 29, 1923.

13 "Desecuritization" is regarded as the process of taking an issue out of the realm of security and starting to deal with it through normal political rules - rather than through the logic of the state of exception. See: Buzan, Waever, and de Wilde (1998).

${ }^{14}$ This section takes 2001 as the year when the desecuritization process started in Turkey, instead of 1999 when Turkey was officially accepted as a candidate for EU accession and when the reform process was first launched. This is because even in 2000, the security speech act was still used regarding ethnic minority rights. At the same time when Prime Minister Ecevit was promising to give more rights to ethnic minorities at the European Council in Nice (7-10 December 2000), the Turkish Armed Forces
} 
passed eight EU harmonisation packages. Through the adoption of these packages, the country entered into an unprecedented process of reform in the fields of democracy, minority rights and human rights. Even in those areas which had been constructed as top security issues in Turkey, a process of desecuritization started; when reforms gained significant impetus in 2001. As a clear attempt at demilitarization (if not desecuritization); the role and composition of the National Security Council (NSC) were amended by several harmonisation packages through which the number of civilian members of the NSC was increased and its role was diminished to that of an advisory nature.

Through a series of harmonisation packages, rights of education and broadcasting in mother tongue were granted to minorities and these reforms have been implemented although the process had worked slowly sometimes. The State of Emergency in southeast Turkey was also completely lifted in 2002. Death penalty was abandoned and State Security Courts were removed. These can all be regarded as acts of desecuritization, because, once national security taboos, they have become openly discussed in public and laws were passed, taking these issues out of the realm of security and placing them into the realm of normal politics where they were dealt with through the use of ordinary measures.

Acts of desecuritization have usually been made by civilian actors in Turkey; mainly by the government and the Grand National Assembly. NGOs and business organisations have produced significant input for economic, political, and social reform in the country through lobbying, campaigning and publishing regular reports on Turkey's basic concerns. Their efforts have raised public awareness and support for those reforms. On the other hand, the members of the Turkish Armed Forces (TAF) had also refrained from using the security speech act over sensitive issues such as minority rights, in the period between 2001 and 2004. The TAF's attitude in this regard can be viewed as a sign of its support for political reforms and Turkey's membership in the EU. Surely, this attitude by the TAF has significantly contributed to the process of desecuritization in Turkey.

It should also be noted at this point that a ripe social, political and economic context made the political reforms possible, especially in the years between 2001 and 2005. The EU's declaration of Turkey as an official candidate for membership in 1999, the capture of the PKK's leader Öcalan and the TAF's gaining upper hand in its low-intensity conflict with the PKK were the major factors which facilitated

issued a report stating that giving rights (such as education and broadcasting in Kurdish) would divide Turkey (Milliyet, 2000). 
the process. A receiving/approving audience due, mainly, to this ripe context, should not also be overlooked ${ }^{15}$.

Despite these developments, the process of desecuritization in Turkey has been rather partial, premature and limited in nature. Furthermore, a reform fatigue has also been observed after the year 2005 in terms of Turkey's fulfilment of the Copenhagen Criteria. However, although there have been times when terrorist attacks by the PKK intensified and caused intensive use of the security speech act, a state of emergency has not been declared (as in the previous cases) and only a few security check points have been established near the Iraqi border. None of the cultural rights given to the Kurdish population were withdrawn and these rights were not even mentioned in any security speech act within the context of those developments. In other words, re-securitization did not occur. The limited desecuritization achieved in this period formed the basis for an attempt at a 'democratic opening' in 2009 (which failed); and then, the AKP government started a resolution process with regard to the Kurdish issue in early 2013 and negotiations between the PKK's leader Öcalan (who is in jail) and government (mostly intelligence) officials were launched. However, it is too early to read this "peace process" as desecuritization, because political actors might be instrumentalizing the whole process ${ }^{16}$. Nevertheless, it can be argued that if it succeeds, it will be a crucial step for desecuritization in Turkey.

On the other hand, it should be kept in mind that desecuritization is not an allout process. Securitization and desecuritization usually happen simultaneously in a society. In other words, some certain issues might be desecuritized while some others are securitized. For example, when one names the EU a desecuritization project/process, he/she cannot overlook that the EU has been securitizing several issues at the same time ${ }^{17}$. Thus, it would not also make sense to claim that what happened in Turkey was not desecuritization (with regard to ethnic minority rights, for example) because Turkey was securitizing some other issues (such as proselytization) at the same time. What makes one to argue that the EU is a desecuritization process is not that it has not securitized anything; but it means that its prominent characteristic is desecuritization. In the case of Turkey, in the years between 2001 and 2007, the prominent feature of Turkish political scene was precarious desecuritization based on democratic reforms, especially with regard to the Kurdish issue which actually extended into resolution efforts on both sides after

\footnotetext{
${ }^{15}$ It should be noted that when the reform process started, public support for Turkey's accession to the EU was $75 \%$ in 2001 (European Commission, 2002b).

${ }^{16}$ Because the AKP government lost its tendency for more reform in the recent years and has taken on an increasingly authoritarian stance in general, the peace process may also be at risk.

17 For example, while European integration has been on track as a desecuritization process, fragmentation was securitized at the same time. (Waever, 1995)
} 
2009. It was precarious because it was heavily dependent on the strategic choices of political actors who act mostly on their own interests; especially to gain more votes. On the other hand, this article argues that the prominent feature of Turkish politics and security is no longer desecuritization. Today's major characteristic is gradual over-securitization with a changed security referent in the country.

\subsection{Gradual Over-securitization after 2007}

Developments about the presidential elections in Turkey in April 2007 which led first to a military e-memorandum and finally to early parliamentary elections revealed the vulnerabilities of the desecuritization/democratization process in the country. However, subsequent AKP governments have forged a process of demilitarization in Turkey. Through this process, the TAF have been placed under strict political and judicial control. The military now remains in the confines of its major function of territorial defence ${ }^{18}$ and performs its crisis management functions abroad.

Nevertheless, it should be underlined that demilitarization does not mean and does not necessarily result in desecuritization. This has also been the case in Turkey and while the military lost its primary role as a securitizing actor; a new and different course of multiple securitizations started in the country, especially after 2007 when the AKP consolidated its power in the parliamentary elections. There has long been an increased divide between the seculars and the AKP (and its supporters), and, securitization against the Islamists by the secular elites had been countered by the AKP and its supporters. For some time, many actors employed the security speech act against each other and on various referent objects; the state being only one of them. The major securitizing actors in this phase of securitization (2007-2011) had been the public prosecutors, almost everyone from the government, the opposition, the media and civil society representing both sides (the seculars, and, the AKP and its supporters).

Gradually, the AKP government replaced the state as the major security referent, especially after 2010. Furthermore, state survival has been associated and equated with the survival of the AKP government and its leaders. The survival of the government has preceded the survival of any other referents in many occasions. Any opposition against the AKP government and its leaders were countered by security speech act and extraordinary measures; naming opponents either as plotting a coup against the government or as terrorists. Especially, the secularist opposition was eroded through a series of lawsuits (the so-called Ergenekon and Balyoz cases). Retired and active military officers (including generals), academics,

\footnotetext{
${ }^{18}$ It should be noted that because of the recent peace process with the PKK, the low-intensity military conflict that had been going on between the terrorists and the TAF has stalled.
} 
journalists and many other people were arrested and sent to jail for plotting a coup to overthrow the AKP government with prolonged detention periods (without trial or during trials). As another sign of excessive securitization in the country, especially freedoms of expression and press have been restricted.

Two major developments - Gezi protests of May-June 2013, and, the wave of arrests that public prosecutors and police forces waged against members of government and their families on December 17-25, 2013, upon corruption claims led to more securitization in Turkey, because the major security referent, the AKP government was severely threatened by the two instances. In both cases, the government resorted to the excessive use of the security speech act to be followed by extraordinary measures against a wide range of people who got involved or supported these events; representing over-securitization. In the Gezi uprising, the protestors, and, in the 17-25 December corruption allegations, public prosecutors and the police were named as terrorists trying to overthrow the government. The intensive use of security speech act helped legitimize the use of extraordinary measures such as the use of excessive and disproportionate force by the police to disperse protesters in the case of Gezi uprising, and, reassignment and demotion of hundreds of police officers and public prosecutors in 17-25 December corruption allegations. Furthermore, the government also brought a ban on social media outlets such as Twitter and Youtube (which appeared to be temporary), and, later, it passed a new internet law on September 9, 2014, in an attempt to make sure that the use of social media in acts against the government (such as the Gezi protests or the leaks of corruption allegations) would not recur (Hürriyet Daily News, 2014).

The swings from desecuritization to over-securitization in the country reveal that although power shifted hands (from the secular military elites to the AKP), the security practice has remained the same, with a crucial difference: the major security referent in the country changed. The major security referent is now the AKP and its leaders and the state's security has increasingly been associated with their survival. Turkey's foreign policy has also been affected by these swings and Turkey's perceptions of and policies for international security have also changed accordingly.

\subsection{Turkey's approach to International Security}

Before the AKP government consolidated its rule in 2007, the military had played prominent role in Turkish foreign policy over a wide range of issues from relations with Syria, Iran, and Israel to the Turkish-Greek disputes, the Cyprus problem and also to relations with the EU. ${ }^{19}$ Major issues which topped the list of external threats in the National Security Policy Document (NSPD) of the country -

\footnotetext{
${ }^{19}$ For a detailed analysis of the military's role in Turkish foreign policy, see: Özcan (2002).
} 
as leaked in the press ${ }^{20}$ - had been the Aegean disputes with Greece, the Cyprus issue, Iran's tendency to export its regime, foreign support for the PKK (by Greece, Iran, Syria, etc.), and the Armenian genocide allegations. On the other hand, Turkey has mainly pursued a multilateralist policy in its approach international security, aligning itself with the West. As a member of the UN, NATO and the OSCE, it aimed to contribute to international security through various ways. It also showed enormous efforts to become a non-permanent member of the UN Security Council, becoming one in the years 2009-2010.

Turkey's foreign policy and its approach to international security had changed fundamentally with the AKP governments, especially after the military's role was curbed in Turkish politics and when Ahmet Davutoğlu took office as the country's Foreign Minister. In efforts which can also be read as attempts at desecuritization in its foreign policy ${ }^{21}$, Turkey improved its trade ties with Iran; accepted the Annan Plan for Cyprus which led to a referendum on the island in 2004 but resulted in the rejection of the plan by Greek Cypriots; started rapprochement with Syria; further improved in its relations with Greece (building upon the rapprochement which was initiated by Ismail Cem and Georgios Papandreou), and signed Protocols with Armenia in 2009 (which have not been ratified by the parties). These were all significant developments which marked the foreign and security policies of the first two AKP governments.

\subsubsection{Soft Security}

In the initial years of Davutoğlu's foreign ministry, the country adopted a soft security approach; waging a "zero problems with neighbours" campaign based on negotiation and cooperation (for example, with Syria and Armenia); providing significant amounts of humanitarian and development aid $^{22}$ to various countries affected by conflicts or scarcity of natural resources (especially through the Turkish Cooperation and Coordination Agency - TIKA); and engaging in mediation/facilitation efforts ${ }^{23}$ in its neighbourhood. It has also engaged in democracy promotion ${ }^{24}$, trying to present itself as a model of democratization for countries intensively populated by Muslims. Through the democratic reforms that it had undertaken for harmonisation with the EU, it has also found ground for presenting itself as pursuing a norms/values-based foreign policy ${ }^{25}$. Surely, this

\footnotetext{
${ }^{20}$ For example see: Şardan (2003).

${ }^{21}$ See, for example, Aras and Karakaya Polat (2008).

${ }^{22}$ On Turkey's development aid policy, see, for example, Tank (2013). On figures of Turkey's net Official Development Assistance, see OECD (2014).

${ }^{23}$ On Turkey's mediation/facilitation efforts, see, for example: Aras (2012).

${ }^{24}$ On Turkey's democracy promotion efforts, see: Aydın Düzgit and Keyman (2014)

${ }^{25}$ See, for example, Prime Minister Erdoğan's statement regarding Turkish foreign policy: "We defend justice, peace, law, and democracy in every area. We, as a conservative and democratic party, are
} 
does not mean that Turkey has become a "normative power" - a term, the author of this article finds rather problematic (not only for defining Turkey but also the EU or the US, or any other global actor) ${ }^{26}$. It only means that the democratic reforms in Turkey have helped legitimize and facilitated its quest for "soft" security actorness.

On the other hand, Turkey's official documents on international security have also been written in such a way to convey how it shares the threat definitions of major global actors, such as the US and the EU; as stated in their security strategies $^{27}$. Some of the security concerns listed by Davutoğlu's Foreign Ministry are: safeguarding territorial integrity; maintaining peace and stability; contributing to collective defence and crisis management operations (such as peacekeeping, humanitarian operations and police missions); containing ethnic and religious conflicts; preventing the proliferation of weapons of mass destruction and their delivery means; combating asymmetric threats, such as terrorism, sabotage, organized crime, uncontrolled mass movement of people as a consequence of armed conflicts; population explosion in the developing world coupled with poverty and alleviating socio-economic disparities, etc. (Republic of Turkey, Ministry of Foreign Affairs, 2011a). In the same document, the means to deal with such challenges and threats, which mainly have a non-military nature, are also named by the Foreign Ministry as "a broader combination of military, economic, social and political policies". This also shows the security conception of Turkey, which Davutoğlu's Foreign Ministry attempted to convey as part of his emphasis on soft security in the initial years of his ministry.

Turkish foreign policy took a different turn after 2011, with the Arab uprisings and especially the Syrian civil war. Leaving Turkey's traditional policy of preserving the status quo, the AKP government took on a diverging stance, being actively engaged in several Arab countries' internal affairs - supporting Muslim Brotherhood and its variants. This was especially overt in the case of Egypt. The AKP government's support for the armed opposition in Syria, on the other hand, not only ended the process of rapprochement with this country but also raised accusations by several analysts ${ }^{28}$ that Turkey started pursuing a sectarian foreign

struggling to hold both real and normative policy together." "The Changing Balances and the Rising Importance of Turkey", Speech delivered by Prime Minister Erdogan at the International Strategic Research Organization (USAK), (published by Journal of Turkish Weekly, no longer available at http://www.turkishweekly.net/article/341/the-changing-balances-and-the-rising-importance

ofturkey.html); cited here from (Öniş, 2011: 65).

${ }^{26}$ See, for example, Cebeci (2012).

${ }^{27}$ Because Turkey's National Security Policy Document is classified, one has to depend either on the leaks in the press regarding this document or to some other official documents to analyse Turkey's security understanding through primary documents. An important source for the official view in this regard is the Turkish Ministry of Foreign Affairs. See: http://www.mfa.gov.tr/default.en.mfa

${ }^{28}$ See, for example, Tol (2013). 
policy. On the other hand, Turkey accused the international community of not acting effectively against Bashar al Assad (Tol, 2013).

The emergence of the Islamic State of Iraq and the Levant (ISIL) close to its borders mainly due to the Syrian civil war has further complicated the situation for Turkey. 49 Turkish citizens had been kept captive by ISIL for three months (JuneSeptember) in 2014. The AKP government has so far refrained from using the security speech act against ISIL, not naming it as a terrorist group (Hürriyet, 2014). This is significant because contrary to Turkey's traditional position of taking on a similar stance with its Western Allies with regard to the definition of international threats; the AKP government has not completely aligned the country with them this time.

\subsubsection{Hard Security}

Although soft security has been a relatively new addition to Turkey's security culture, the country's traditional emphasis on hard security has always had a significant impact on its approach to international security. The prominence of military security in Turkey's approach had mainly revolved around its understanding of defensive realpolitik and preserving the status quo $^{29}$ and the country preferred to contribute to international security through its various memberships in international security and defence organisations. It has been actively involved in military crisis-management and stabilization efforts in its neighbouring regions as well as globally. The UN and NATO have especially been important venues in which Turkey participated in peacekeeping and crisismanagement operations world-wide ${ }^{30}$. Turkey has also been involved in various EU operations ${ }^{31}$, although there have been severe problems ${ }^{32}$ with Turkey's association with the Union's Common Security and Defence Policy (CSDP) ${ }^{33}$ in the recent years.

\footnotetext{
${ }^{29}$ The only exception to this had been its military intervention in Cyprus, where Turkey used its status as a guarantor to protect Turkish Cypriots. Turkey's intervention in Cyprus and the Cyprus problem itself are rather debatable issues and this study is not the place to discuss them further.

${ }^{30}$ For example, in Somalia (UNITAF, UNOSOM, and UNSOM), Bosnia (UNPROFOR, IFOR, SFOR, etc.), Macedonia (Essential Harvest, Allied Harmony and Amber Fox), Kosovo (KFOR, UNMIK), Congo (MONUC), Sudan (UNMIS), Darfur (UNAMID), Libya (OUP), Iraq (NTM-I), East Timor (UNMISET), Lebanon (UNIFIL), Aghanistan (UNAMA, ISAF), etc.

${ }^{31}$ These operations are: Concordia (Macedonia), EUFOR Althea (Bosnia), EUFOR RD Congo. Turkey also participates in the EU's civilian crisis-management operations, namely, EUPM Bosnia, Proxima (Macedonia), EULEX Kosovo, EUPOL Kinshasa, EUPOL COPPS (Palestine). Turkey is also an observer to the European Gendarmerie Force.

${ }^{32}$ On these problems, see, Cebeci (2011).

${ }^{33}$ European Security and Defence Policy (ESDP) before the adoption of the Lisbon Treaty in 2009.
} 
Turkey has also been involved in various UN and NATO humanitarian operations including, but not limited to, NATO's Katrina support and Pakistan earthquake relief operations. The country further provides humanitarian aid to some countries and regions both through international and bilateral mechanisms. Beyond the rhetoric of Turkey's commitment to peace and security in its region and in the world, these security practices at the regional and global levels can be read as Turkey's preference for multilateralism. This has been a crucial feature of Turkey's security culture.

Turkey has also launched several regional cooperation and security initiatives, which also reflect Turkey's multilateral approach to international security. It initiated the South Eastern Europe Defence Ministerial Process (SEDM) and the linked Multinational Peace Force South-East Europe (MPFSEE). The MPFSEE is designed in such a way to be "available for NATO and EU-led conflict prevention and other peace support operations that will be conducted through a mandate by the UN and/or the OSCE" (Republic of Turkey, Ministry of Foreign Affairs, 2011b). It may also be made available to the coalitions of the willing under the same conditions. Black Sea Naval Cooperation Task Force (BLACKSEAFOR) is also another similar initiative which "is an on-call force enabling the participating countries to join their naval capabilities in order to conduct operations ranging from counter-terrorism to search and rescue, humanitarian assistance, environmental protection operations, mine counter-measures, goodwill visits and any other tasks agreed by all the parties" (Republic of Turkey, Ministry of Foreign Affairs, 2011b).

On the other hand, Turkey's "strategic" culture has mainly been built on its robust military capabilities ${ }^{34}$. Its approach to international security is also intensively based on its military contributions to international crisis management operations ranging from peace-making to post-conflict rehabilitation. Due to their experience in the low-intensity armed conflict with the PKK, as well as their involvement in international crisis management operations, the Turkish Armed Forces are highly flexible, rapidly deployable and sustainable. Their strategic lift and air refuelling capability is especially important in this regard. These characteristics give them significant advantage in conducting crisis-management operations abroad.

Beyond its technical/strategic assets and capabilities, a crucial feature of Turkish crisis management activities is the attention paid to the locals on the ground, in crisis areas, because Turkish troops tend to interact with the local population. Nevertheless, this interaction does not remain limited to NGOs and

\footnotetext{
${ }^{34}$ Please note that the author does not assign any normative meaning to the notion of military capability here.
} 
goes beyond Civil-Military Cooperation (CIMIC) activities. Rather, Turkish troops are respectful of and responsive to the locals' cultural traits and have little hardships in leaving their bases and mixing with the people, as their experience in Bosnia, Kosovo and Afghanistan indicate ${ }^{35}$. For example, Turkish troops in ISAF do not wear sunglasses (in the Afghan desert), respecting the Afghan belief that sunglasses make people see through clothes (Hürriyet, 2005). They do not also wear any bulletproof vests and they do their patrolling on foot rather than in armoured vehicles (Hürriyet 2005). ${ }^{36}$

Turkey's multilateralism, especially in the realm of military security might partly be explained by its defensive Westernization: Surely, acting with the international community has a crucial identity-recognition aspect, because it conveys the image of the country in question as respectful of certain values and norms - values and norms that are mainly represented and pursued by the West. On the other hand, Turkey's military operations abroad also have a psychological impact inside the country because they become issues of "national pride" and identity. This is related with Turkish people's historical identification with the military. It can be argued that the military is embedded in Turkish identity, because, from their existence in Central Asia to the Ottoman Empire and finally to the modern Turkish Republic, the Turks defined themselves as an army-nation ${ }^{37}$. The successes of the military abroad constitute a significant part of their identity because they enhance the people's identification with the Turkish army. The military's embeddedness in Turkish identity can also be seen in the results of the surveys conducted to rank the most trusted institutions in Turkey. The TAF always tops the ranks in these surveys as the most trusted institution in the country ${ }^{38}$.

\footnotetext{
${ }^{35}$ It should be noted that the TAF's stance in their operations inside the country and abroad display certain variations, mainly because the security referents are different. Where the security referent is the state (i.e. where state survival precedes the survival of Turkey's citizens) the TAF may take on a hard handed approach. On the other hand, in its operations abroad where the security referent is either the populations or the states there, the TAF displays significant restraint especially when compared to their European counterparts (e.g. the French troops in Congo).

${ }^{36}$ The historical or cultural ties with the countries given as examples here might also be factor in the TAF's approach. On the other hand, French experience in Congo has been different, for instance, although France has historical ties with the country. Cultural difference might have played a role there, but, more importantly, the nature of the historical relationship - colonization, based on the logic of mission civilisatrice - might be the major factor which caused the French troops' behaviour in Congo (Eckert, 2011).

${ }^{37}$ Conscription can be regarded as an important mechanism in maintaining the identification of the nation with the army in Turkey. On Turkish identity as an army-nation, see, for example: Altınay (2002) and Altınay and Bora (2002).

${ }^{38}$ This is still the case despite the recent Ergenekon and Balyoz trials, which now appear to have been waged with made-up evidence and false witnesses. In an 2012 survey conducted by Kadir Has University, the TAF ranked as the most trusted institution in Turkey with $56.3 \%$ to be followed by the Presidency (of Abdullah Gül) by 53.7 \% (Kadir Has University, 2013).
} 
The TAF's status had been an area of contention between Turkey and the EU for years. Although some Europeans welcomed Turkey's military contributions to international crisis management operations and valued its quest for becoming an EU member also because of its possible strategic contributions to the Union's security and defence policies ${ }^{39}$, others had a totally different view. For the latter, because of the size and the influence of the Turkish military; the country's involvement in the European Security and Defence Policy (ESDP) would render it a Turkish-dominated project (cf. Tofte, 2003: 23). However, despite some negative perceptions regarding the TAF in Europe, it can be contended that Turkey's approach to international security is mainly marked by its multilateralism which can be associated with defensive Westernization. The varying European views about Turkey's place in European security, on the other hand, can also be explained through the differences of security cultures within the EU.

\section{Norms, Identity and Culture in the EU's Security}

The EU was built with a clear security logic: making the recurrence of war between European powers unthinkable. This is why Waever (1998a) regards European "integration as security". Its success in achieving peace has also made many scholars/practitioners argue that the EU is a model of peaceful regional integration (e.g., Barroso, 2009; Alecu de Flers and Regelsberger, 2005). Some further name it as a "normative power" mainly because it represents a virtuous example (Manners 2002; and 2008: 76) and conveys its norms and values to other regions and countries through various mechanisms such as enlargement/trade conditionality.

On the other hand, securitization takes place at different levels and across a wide range of issues in the EU, from fragmentation to immigration. The launch of foreign policy cooperation with the European Political Cooperation, its replacement by the Common Foreign and Security Policy (CFSP) and the final creation of a security and defence policy ESDP/CSDP have been significant developments which marked the EU's approach to international security. The European Security Strategy (ESS) which was adopted in December 2003 and the Report on its Implementation issued in 2008 remain as the major documents which listed the threats to the Union and the means to tackle them; reflecting the EU's security culture.

\subsection{The Culture of Desecuritization and the Arguments on the EU's Normative Power}

Europe had traditionally been the platform for great power rivalries, balance of power politics and alliances. Nevertheless, after World War II, this has changed

\footnotetext{
${ }^{39}$ See, for example, Schröder (2011) and European Commission (1999).
} 
gradually. In the immediate aftermath of World War II, the issue at hand was to put an end to rivalry between major European powers and to erase the devastating effects of war through intensive reconstruction and restoration. Therefore, major European security concerns revolved around a reconstruction of the economies of war-torn European countries and avoidance of war between European powers by way of keeping Germany under control without excluding it from newly established European structures. The security argument behind European integration was thus not of "assuring a good, stable security system, but of avoiding security concerns being directed at each other [...] by somehow circumventing this traditional logic, directing energies elsewhere" (Waever, 1998b: 83). Thus, the main aim of European integration was making war between European powers " "not merely unthinkable, but materially impossible' through the creation of a "common higher authority" (Hill and Smith, 2000: 12) ${ }^{40}$. This meant the establishment of a non-war community ${ }^{41}$ - "a centred geopolitical structure" (instead of a multi-centred power structure) which would revolve around the Franco-German core (Waever, 1998a and 2000). This is why Waever defines the EU as a desecuritization project and process (Waever, 1998b and 2000) in which European powers stopped regarding each other in security terms and normalised their relations. In his view, "[i]t is the process of integration, not its outcome, that is the most important peace-causing effect of the European enterprise" (Waever, 1998a: 46).

Waever (1998b and 2000) argues that the EU's major security function is "keeping its core intact" through integration. It is also this strong European core that draws/attracts other states towards the EU and enables the Union to exert a "silent disciplining power" on those states by offering them the prospect of membership in the Union ${ }^{42}$, in Waever's view (1998b: 100-101, 1998a: 46). This silent disciplining power can also be observed in the EU's relations with countries which seek to have closer trade relations with the Union; however, it works best in the case of enlargement, because the incentive is bigger ${ }^{43}$. Conditionality is the major mechanism through which the EU exerts its silent disciplining power. Those countries which seek to have closer ties with the EU or become its members have

\footnotetext{
${ }^{40}$ Through the establishment of the European Coal and Steel Community in the first place.

${ }^{41}$ For an argument on the non-war community character of the European integration project, see Waever, (1998b: 104).

${ }^{42}$ A consideration of the accession processes of the CEECs would testify to this argument.

${ }^{43}$ It should be noted at this point that the EU's silent disciplining power, or its transformative power, so to speak, is no longer as effective as in the case of its Eastern enlargement. There are several reasons for it. One of which is rivalling countries' increasing impact in its neighbourhood. Russia represents the most important challenge in this regard, as we have seen in the recent developments in Ukraine. For more on this, see: Grabbe (2014).
} 
to fulfil certain economic and political conditions set by the Union according to its own values and norms, which are usually represented as universal ${ }^{44}$.

The EU aims to project its model and its values/norms to other regions and countries mainly through the use of civilian/soft means rather than military ones. This is why it has long been regarded as a "civilian power" 45 . On the other hand, there is also a dominant literature in European Studies which names the EU as a "normative power" ${ }^{46}$ because of the Union's diffusion of its values and norms (such as democracy, peace, and respect for human rights) to other regions and countries through civilian means. Nevertheless, the concept of normative power itself and the arguments that the EU is a normative power are not uncontested. In many cases, the discourse of the EU's normative power legitimizes the EU's practices which might be perceived by some as neo-colonial, helping Member States pursue their own interests especially in their former colonies under an EU $\operatorname{cover}^{47}$. Furthermore, the "normative power Europe" discourse inevitably puts the EU to a superior position against its others, which again resonates with the idea of mission civilisatrice - an important feature of colonial practice ${ }^{48}$.

\subsection{Securitization in Europe}

Although they enjoy peace within the EU's borders, Europeans also tend to securitize many issues. In the Cold War era the major threat directed against Western Europe was regarded as the Soviet threat. After the end of the Cold War and the removal of its overlaying impact, Europeans started securitizing a diversified range of issues from the environment to immigration. "[A] return to its past" - i.e. the revival of state-to-state rivalry and war among European states i.e., fragmentation - has also been securitized (Waever, 1998a, 1998b, and 2000). The dichotomy between integration and fragmentation has frequently been used as part of the security discourse in Europe within this context.

Turkey's accession to the EU has also been portrayed as a threat to European integration by some Europeans (especially Christian Democrats) such as Valerie Giscard d'Estaing ${ }^{49}$. Although enlargement has usually engendered intensive debate in the EU circles as a factor impeding further integration, its possible negative implications have been avoided through the adoption of parallel processes of deepening and widening. Despite the use of exaggerated societal security discourse which was symbolized by the word "the Polish plumber", enlargement

\footnotetext{
${ }^{44}$ On a criticism of such representation, see: Merlingen and Ostrauskaité (2006: 17).

${ }^{45}$ See: Duchêne (1972).

${ }^{46}$ See, for example: Manners (2002 and 2006) and Diez (2005).

${ }^{47}$ See, for example: Cebeci (2012) and Fisher Onar and Nicolaïdis (2013).

${ }^{48}$ For criticisms of the normative power Europe discourse, see: Merlingen (2007) and Cebeci (2012).

${ }^{49}$ For d'Estaing's remarks, see: Castle (2002) and Black (2002).
} 
towards Central and Eastern European countries in 2000s was not securitized whereas Turkey's quest for full membership in the EU was presented as a threat to Europe. Crucial for understanding the securitization of Turkey's accession to the EU are the debates on fragmentation and integration in Europe. On the other hand, the UK's possible exit from the EU, and, the Greek Euro-crisis have recently been highly debated issues over which the security speech act has been used with regard to the threat of fragmentation.

Illegal immigration from other countries (which specially got exacerbated by the Arab uprisings and especially the Syrian refugee crisis) has also been another crucial issue which has been heavily securitized by Europeans. Bordermanagement has thus topped the EU's security agenda. The Union has also introduced several initiatives for cooperation with third countries in this regard. For example, border management has been underlined several times in the revised European Neighbourhood policy documents (e.g., European Commission and High Representative of the Union for Foreign Affairs and Security Policy 2011). On the other hand, FRONTEX has also become one of the major security devices for tackling illegal immigration.

The EU adopted a Counter-Terrorism Strategy in 2005, an Internal Security Strategy in 2010, and a Cyber Security Strategy in 2013 to tackle internal threats such as organised crime, terrorism, radicalization, cybercrimes, and, natural or man-made disasters. All these are cross-border threats but they affect internal security at the same time. Therefore, the EU approaches them through a logic which is expressed in its Internal Security Strategy as: "protecting people in Europe within a global society" (Council of the European Union, 2010).

On the other hand, terrorism, proliferation of weapons of mass destruction, organized crime, and regional conflicts are only a few of the external issues which the EU securitizes. In December 2003, the EU announced its first ever security strategy in which these threats were listed. In 2008 a "Report on the Implementation of the European Security Strategy" was adopted which underlined new/additional security issues for the EU, such as energy security and cyber security. European Security Strategy is a crucial document for reference to grasp the Union's threat definition. Furthermore, it is especially important for assessing how the EU conveys its security identity to the world.

\subsection{European Security Strategy and the EU's Security Culture}

Reminding Waever's argument that the EU's most important security function is "keeping its core intact" (Waever, 1998b), the ESS starts with specific reference to the transformative impact of the EU in Member States, underlining that "European countries are committed to dealing peacefully with disputes and to cooperating through common institutions" (Solana, 2003). On the other hand, the 
ESS emphasizes the EU's promotion of norms and values in the following statement: "The best protection for our security is a world of well-governed democratic states. Spreading good governance, supporting social and political reform, dealing with corruption and abuse of power, establishing the rule of law and protecting human rights are the best means of strengthening the international order." (Solana, 2003) This statement does not only emphasize the image of a normative power that the EU aims to convey, but it is also interpreted as part of the Union's holistic approach to security (Delcourt and Remacle, 2009: 242). The use of its wide range of tools through which the EU aims "to build a ring of wellgoverned countries to the east of the EU and on the borders of the Mediterranean" (Solana, 2003) has also been seen and presented as part of the EU's holistic approach to security. On the other hand, practice of building a ring of well governed countries around Europe might also be read as another manifestation of the EU's silent disciplining power (Waever, 1998a: 46; 1998b: 100-101).

"Effective multilateralism" constitutes an important part of the ESS, as a feature put forward to mark EU's difference, especially from the US, right at a time when the latter invaded Iraq without seeking a clear UN mandate. The ESS underlined respect for international law and cooperation, through setting " $[\mathrm{t}] \mathrm{he}$ development of a stronger international society, well functioning international institutions and a rule-based international order" as an objective. Thus, the EU's identity both as a security community and a normative power was successfully reproduced.

The tools listed in the ESS for achieving its aims are also significant. There is a clear preference for using a mixture of instruments and for tackling the root causes of global challenges and key threats in the ESS. Many analysts argue that although military instruments are cited as usable tools in crisis and post-crisis situations, this does not overshadow the EU's nature as a civilian power (e.g., Whitman, 2006: 9). Military means are mentioned in the ESS rather as instruments to be used only as a last resort. The preference in the ESS for the use of the term "preventive engagement" instead of "pre-emptive engagement" also reflects the EU's choice for softer means.

The threat definition of the ESS is also reflective of the EU's security culture. Key threats to European security that are listed in the ESS are what many refer to as global threats: terrorism, proliferation of Weapons of Mass Destruction, regional conflicts, state failure, and organized crime. Thus, the EU or the EU-Europeans are not the sole security referents with regard to these threats. The Report on the Implementation of the ESS also listed the same threats, albeit with a different order and added new ones to the list; namely, cyber security, energy security, and climate change (Council of the European Union, 2008). 
The ESS was significant in the sense that it was also regarded as a response to the rift between the EU and the US over the Iraq war and also to the US's attitude after the September 11 attacks. It was designed in such a way to show that the EU shared the threat perceptions of the US but did not approve the methods that the latter employed to tackle them. That is why its list of threats was mainly reflective of the international context back then. The Report on the Implementation of the ESS, on the other hand, was prepared in a less limiting context and thus the EU could elaborate more on other threat perceptions such as climate change and energy security.

\subsection{The CSDP and the EU's Security Culture}

The launching of the ESDP was crucial in the sense that it marked the institutionalization of the EU's "conflict prevention function" (cf. Waever, 2000). After the lessons taken from the Yugoslav conflicts and the Gulf crises, the ESDP had been formulated in such a way to endow the EU with the capacity for autonomous action, backed up by credible operational military capabilities, the means to decide to use them, and a readiness to do so, in order to respond to international crises (Presidency Report on Strengthening the Common European Policy on Security and Defence, 1999). Thus, initially, the main function of the ESDP was defined as "crisis management" whereas the Lisbon Treaty took its successor, the CSDP, to a new level with its mutual defence clause.

The Petersberg tasks can be named as the basis on which the ESDP had been built. Revised and updated by the Headline Goal 2010 and by the Lisbon Treaty, the Petersberg tasks still constitute the backbone of the CSDP. The Petersberg tasks are also reflective of the EU's strategic culture. Based on a spectrum ranging from low intensity missions to tasks of combat forces in crisis management and to post-conflict stabilisation, these tasks reflect the EU's "soft power-plus"50 (Haine, 2004) nature since they rely heavily on civilian crisis management capabilities as well as military ones.

The changes in the Petersberg tasks are also reflective of how the ESDP had evolved. Originally WEU tasks, Petersberg tasks were initially designed for mostly humanitarian, peacekeeping and peace-making dimensions of crisis management, according to the requirements of an era marked by the Gulf War and Yugoslav crises. The revisions brought to the Petersberg tasks by Headline Goal 2010 were based not only on the lessons learnt from regional conflicts, but also on the global fight against terrorism which started with the September 11, 2001 attacks. These

\footnotetext{
${ }^{50}$ Haine argues that the use of force, albeit as a last resort, is deemed necessary in specific circumstances and this represents a significant shift from a civilian-only Union. Thus, he defines the EU as "soft power-plus" (Haine, 2004: 52).
} 
new tasks would be joint disarmament operations, support for third countries in combating terrorism and security sector reform; as suggested in the ESS (Headline Goal 2010, 2004). In the period between 2003 and 2008, the EU increasingly got engaged in post-conflict rehabilitation and state-building, especially through civilian crisis management operations, such as rule of law missions and police training. Also reflecting this intensive involvement in post-conflict rehabilitation and restructuring, the Lisbon Treaty (Art. 28B) revised the Petersberg tasks in such a way to include military advice and assistance tasks (replacing security sector reform), conflict prevention, and post-conflict stabilisation. Although the support for third countries in combating terrorism was named as one of the Petersberg tasks in Headline Goal 2010; the Lisbon Treaty changed this and instead stipulated that all Petersberg tasks might contribute to the fight against terrorism, including by supporting third countries in combating terrorism in their territories.

Despite the fact that the Petersberg tasks were enshrined in the Amsterdam Treaty, and, the ESDP was first introduced in 1999, the ESDP could not become operational until 2003; mainly because of the problems with regard to the arrangements to be made for NATO-EU cooperation. ${ }^{51}$ The premature ESDP especially suffered from turf battles among EU institutions and different strategic cultures of Member States, and, could not respond effectively to major global challenges despite its institutional development and operational activity. It was upon the Union's revealed discrepancy over the Iraq War that the Member States felt the need to review EU foreign policy and revise it in such a way to display actor capability in global affairs.

On the other hand, Merlingen and Ostrauskaite (2006: 2) contend that "[s]ecurity and defence is the area in which the EU has advanced most in recent years". The first step taken for overcoming the ESDP's discrepancy was the adoption of the ESS in December 2003. The ESS and the 2008 Report on its implementation provided the Member States with guidelines on which they would base their foreign and security policies and act in a coordinated and coherent manner. Perhaps, the EU would not be able to act as a unitary actor, but the Member States would at least have a reference point for common action. Besides the extension of the Petersberg tasks, some other adjustments were also made to facilitate EU foreign and security policy action in terms of tasks, institutions, procedures and capabilities. The European Defence Agency (EDA) was

\footnotetext{
${ }^{51}$ Although the ESDP was declared operational by the Laeken European Council of 14-15 December 2001, it could not become operational in practice before the NATO-EU Declaration on ESDP (16 December 2002) and the adoption of the Berlin-Plus Arrangements on 17 March 2003.Thus, the EU could only launch its first military crisis management operation Concordia, in Macedonia, on March 31, 2003, albeit its Police mission in Bosnia started a bit earlier, on March 1, 2003.
} 
established, the Battle Groups concept was introduced, and a new Headline Goal for the ESDP was adopted in the years 2004-2007.

Once the ESDP operations became operational, the EU's civilian and military crisis management troops have been deployed in various parts of the world. The Union's civilian crisis management operations and especially its post-rehabilitation activities have been on track since 2003. In its military crisis management operations, the EU has given special importance to CIMIC activities on the ground. Nevertheless, these activities have usually been limited to the civil society organisations, and, European troops (apart from a few national groups, such as Italians) do not prefer to mix with the locals.

The EU's military operations (either operations made through the use of NATO assets and capabilities or EU-only operations) have rather been limited in nature and some of them have mainly been designed according to the national interests of some Member States (France, taking the lead in this regard). In many cases, military action could only be possible when the related operation did not touch the national sensitivities/interests of the Member States. This might also be the reason for their limited nature. Edwards (2006: 16) contends:

\begin{abstract}
The range of these missions and the practical experience gained in their planning and management as well as their successful conclusion has engendered growing respect; that, however much the EU tends to talk about process rather than take action, there has been action, limited though it may have been. [...] their global reach raises some suspicion that the missions, especially those beyond Europe's "neighbourhood", are responses to particular member state concerns; that in an important sense the missions are driving strategy rather than the reverse.
\end{abstract}

The Lisbon Treaty can also be read as an attempt to overcome problems of coherence in and national differences over the Union's security and defence policy. The novelties that it brought to the ESDP can also be interpreted as contributions to the creation of the EU's "strategic culture". Renaming the ESDP as "Common Security and Defence Policy" signified a new step towards common defence. The EDA which was introduced in 2004 also found its legal basis with the Lisbon Treaty. It is an important institution which aims at the harmonization of the defence structures of EU Member States. As a mechanism for joint procurement and pooling demand (e.g., for logistics), the EDA is crucial for overcoming differences in national cultures and for creating a European "strategic culture" ${ }^{, 52}$. Furthermore, the Lisbon Treaty introduced the concept of Permanent Structured Cooperation (PSC); which was designed to provide a platform for "those Member States whose military capabilities fulfil higher criteria and which have made more binding commitments to one another in this area with a view to

${ }^{52}$ See, for example, Biava, Drent, and Herd (2011: 1239). 
the most demanding missions" (Art. 28A[6]). Although its major aim is better coordination among those member states which are willing to go on with defence integration and which have the ability to do so; it may also carry the risk of further divisions within the CSDP. Furthermore, those "higher criteria" have still not been set. Despite some debates in 2009 and 2010, the Member States have not shown further interest in pursuing the PSC.

On the other hand, the most significant novelties of the Lisbon Treaty have been the solidarity and mutual assistance clauses. The solidarity clause in the Treaty on the Functioning of the EU (Article 188R) stipulates that in case a Member State becomes "the object of a terrorist attack or the victim of a natural or man-made disaster," the EU and its member states "shall act jointly in a spirit of solidarity" and "[t]he Union shall mobilize all the instruments at its disposal, including military forces made available by Member States". This can be read as part of the EU's Counter-Terrorism Strategy which represents its response to the terrorist attacks in Madrid (March 11, 2004) and London (July 7, 2005). It is important for emphasizing solidarity among Member States - a characteristic, which can be viewed as one of the major principles for the creation of a common security culture as well as a common identity.

The mutual assistance clause in the Lisbon Treaty can also be read as an attempt at the creation of a common identity as well as at the gradual creation of common defence. Article 28A (7) of the Lisbon Treaty stipulates:

if a Member State is the victim of armed aggression on its territory, the other Member States shall have towards it an obligation of aid and assistance by all the means in their power, in accordance with Article 51 of the United Nations Charter. This shall not prejudice the specific character of the security and defence policy of certain Member States.

The provisions on mutual assistance are especially significant for the creation of a European security culture as they determine and reflect its foundations. The term "by all means", for example, can be read as a manifestation of the EU's holistic approach to security which partly rests on the employment of a wide range of tools from military to civilian ones. The statement "this shall not prejudice the specific character of the security and defence policy of certain Member States" is not unique to the Lisbon Treaty but inserted in all the relevant treaties and official documents of the EU. Although not spelled out in the statement, this provision is especially designed for the NATO commitments of EU Member States, which are also members of the Alliance. It can also be interpreted as a crucial reference to the specific security cultures of member states which manifest themselves either in membership of alliances such as NATO or in neutrality as in the case of Austria, Finland and Sweden. 
All in all, the Lisbon Treaty can be seen as a document which helps the creation of a European security culture. Nevertheless, the most important element for the effectiveness of the CSDP and the creation of a common European security culture is still missing: political will on the part of the member states. This brings the issue of different security cultures of the EU Member States to the fore.

\subsection{Different Security Cultures in the EU: United in Diversity?}

Although the EU is in the process of creating its own security culture, its Member States also have their own national security cultures and they are not homogenous. On the one hand, some EU Member States (e.g., Finland, Sweden and Austria) are neutral (or non-aligned) but they are in the CSDP, on the other, some are NATO Allies (e.g., the UK, France, Germany,) whilst Denmark is in NATO but has an opt-out from CSDP. Some Member States are Atlanticists (e.g., Britain and Denmark) and some are Europeanists (e.g., France and Belgium, and recently Germany). Some are micro states (e.g., Malta and Luxembourg) and some are imperial/colonial powers (e.g., France and the UK). Some have highly developed defence structures and capabilities (e.g., France and the UK), while some do not. Some spend more on their defence (e.g., Greece), some cut their defence budgets (e.g. Spain). Some put more emphasis on territorial defence (especially, Central and Eastern European Countries, as well as Finland) and their sovereignty, while some prefer security (e.g., Germany). This is because "[a]t the national level, $[\ldots]$, there are competing discourses within member states born of different interpretations of history, geography, the political system, etc, that bear on the question of $a$ national culture." (Edwards, 2006: 8, emphasis original)

The problems with the member states' different security cultures revealed themselves in an unprecedented way during the first phase of the Iraq War. Member States were divided and could not display a common EU stance on the war. Furthermore, another huge rift took place between the EU and the US, and, the Member States could not handle this situation very well. The US had also become a major source of division within Europe. Donald Rumsfeld's famous comments which started the debate over "old Europe versus new Europe" (US Department of Defence, 2003) marked the divide in the EU. Although these initial differences among EU Member States softened considerably in the aftermath of the Iraq War, they revealed the major problems with cohesion within the Union.

On the other hand, there are huge power disparities between EU Member States. Their defence structures and operation styles are different. ${ }^{53}$ The EDA could

\footnotetext{
${ }^{53}$ Italian and French experiences on the ground in Afghanistan testify to such an argument. While the French troops' major concentration is their military activities, the Italians empathize more with the local people (Ruffa 2011:96).
} 
not also succeed in helping member states harmonize their military capabilities. Furthermore, Member States have divergent views with regard to the aims of the EDA. Quille (2009: 5-6) contends that France tends to see the EDA mainly as an "armaments agency" while the UK is views it as a mere "capability development agency". This clearly shows how the EU Member States have significantly different understandings with regard to the development of the EU's defence capabilities as set by the Lisbon Treaty.

EU Member States cannot also agree with each other on the "legalisation of the use of force" (Margaras, 2010: 9). While some of them regard a UN Security Council mandate as a prerequisite for the use of force, others do not necessarily seek such a mandate (Margaras, 2010: 9). Margaras sees this as a problem for the development of a common EU strategic culture. He contends:

The 'soft' approach on the use of force, the development of a selective humanitarian
agenda, the Petersberg Tasks and the acceptance of a Civilian Crisis Management as
tools of intervention are the cornerstone values of the strategic culture of the EU, but
the acquisition of a UN Security Council Mandate and the question of the NATO-EU
relationship constitute grey areas in the cognitive map of this common culture.
(Margaras, 2010: 6)

The French and British approach in Libya, in 2011, is an example of how even the UN Mandate can be stretched and interpreted according to national interests ${ }^{55}$. Although they acted together, French and British motives for intervening in Libya were also different (Davidson, 2013). Both states had trade/energy interests (although France had more stakes than the UK) and public opinion in both countries was in favour of intervention. However, France had more stakes not only because of its historical colonial ties in the region but also because of the risk of refugee influx from Libya. Germany, on the other hand, opposed the intervention. The Libyan case clearly showed the differences among EU Member States. It has become clear once again that France and the UK (as former imperial/colonial powers) are countries which do not hesitate to pursue realpolitik when they see fit. On the other hand, foreign intervention is still a sensitive issue for Germany and although it has removed constitutional restraints in this regard, it still pursues a rather cautious foreign policy.

All in all, it can be stated that EU Member States have crucial differences in their security cultures. This sometimes has negative implications for the EU's security and defence policies. Nevertheless, the EU still has a security culture in

\footnotetext{
${ }^{54}$ Haine (2005: 52) also argues that each time the EU attempts to launch an operation, it has to delegate the decision to use force to national governments.

55 The UN Security Council Resolution 1973 over the establishment of a no-fly zone in Libya and protection of civilians was used for overthrowing the Qaddafi regime (Ulfstein and Christiansen, 2013).
} 
the making. A holistic approach to security, multilateralism and a clear preference for civilian means over military ones form the basis for this culture.

\section{Turkish and European Security Cultures in Perspective}

Turkey and the EU are actors with different security cultures. Turkey, as a state, has rather interest-driven, geopolitical/geostrategic, realpolitik-based (cf. Karaosmanoğlu 2000 and 2009) approach to security, whereas, the EU, as an international organisation, claims that it pursues normative and value-oriented approach - although its normative stance is open to question in many instances ${ }^{56}$ and national interests of its Member States may usually render its policies ineffective in this regard. Turkey has usually emphasized military/hard power, mainly based on the argument that it is located in a tough neighbourhood, perceiving threats to its territorial integrity and national unity; while the EU represents itself as a civilian/soft power; free of an armed threat against its territories and enjoying peace within its borders. The military's place in politics in Turkey had been a significant case in point for years, which could also be associated with its political and security culture. In Europe, civilian control of the military is considered as a crucial ingredient of democracy. ${ }^{57}$ These different perceptions and conceptions have roots in the political and security cultures of both entities.

Despite their distinct cultures and different approaches, the EU and Turkey actually share many security concerns such as terrorism, proliferation of weapons of mass destruction, regional conflicts, organized crime, cyber security and energy security. Nevertheless, they attach different priorities to these issues. Turkey prioritizes terrorism whereas the EU is more concerned with regional conflicts, energy security and climate change. On the other hand, geographical priorities of the EU and Turkey are actually similar. Both have been concerned with their shared neighbourhood - the Balkans and the Middle East.

Notwithstanding some similarities in their security perceptions, the EU and Turkey employ different methods to tackle them. The EU tends to employ diplomacy and economic means to deal with security challenges and regards the use of force as a last resort. Turkey, on the other hand, mainly because it perceives a threat to its territorial integrity, inclines to use military means when it sees fit. However, Turkey has also started employing its soft power in relations with its neighbours and in the world (for example, in the Balkans, in Africa, etc.) through

\footnotetext{
${ }^{56}$ For example the Arab uprisings have openly revealed the discrepancies in the EU's normative stance in the sense that the EU had actually supported authoritarian regimes in the region for years. Only this example alone puts the EU's normative identity in doubt.

${ }^{57}$ See several Commission Reports on Turkey for such an emphasis.
} 
the use of humanitarian and economic tools. Its emphasis on military power remains, albeit with a changed status of its military and its civil-military relations. ${ }^{58}$

The difference between Turkey and the EU with regard to their choice over hard/soft power is especially apparent in their approach to terrorism. Whereas the EU's strategy against terrorism involves tackling the root causes; Turkey has mainly used military means to tackle the threat of separatist terrorism that it perceives from the PKK. Nevertheless, September 11 attacks have led to a considerable difference in the EU's approach both to terrorism and to Turkey. For the first time in its history, the EU recognized the PKK as a terrorist organisation in 2002. This was actually a significant step on the EU's part when it is considered that many European capitals were sympathetic towards the PKK. On the other hand, Turkey has attempted to deal with the root causes of terrorism after 2001; extending the scope of minority rights; dealing with the problems of socially and economically deprived regions; and starting a "peace process" with the PKK in 2013. Furthermore, the non-military measures (such as education and health programmes) adopted by the Turkish government, the TAF, and several NGOs for the development of Turkey's south-eastern region have also been welcomed by the EU. Notwithstanding their differences of approach towards tackling terrorism, Turkey and the EU could at least find a ground on which to close the gap between them in this regard.

One of the major differences between Turkey and the EU in their conception of security is that Turkey takes the state as the ends whereas the EU regards it as a means in the security process. In Turkey security of the state (currently associated with the survival of the AKP government) precedes individual security. Turkey has mainly been an over-securitizing actor (with the exception of a slight desecuritization in the first few years of 2000s); whereas EU integration itself is a desecuritization process. In Turkey anything from education to relations with the EU has been securitized with reference to the state, and, now, primarily with reference to the AKP government and its leaders. On the other hand, the EU refrains from attaching a security tag to almost everything and tends to deal with problems in the political realm. Furthermore, threats are defined in such a way to avoid the negative impacts of securitization, such as limiting individual rights and freedoms. In this sense, it can be contended that the EU has achieved de-securitization not only among its Member States but also within them ${ }^{59}$. The political criteria for

\footnotetext{
${ }^{58}$ Turkey's emphasis on hard power and the predominance of its military in its politics had had a negative impact on the EU. Some Europeans have further used the security speech act in this respect, claiming that Turkey would undermine the nature of the EU as a security community (e.g. Moustakis and Sheehan, 2000).

${ }^{59}$ It should be noted at this point that the recent developments in Hungary signal some problems in this regard.
} 
accession to the Union can be regarded as a requirement to be fulfilled in order to achieve a successful de-securitization of internal problems in candidate countries.

However, it should not be overlooked that some Europeans also securitize the EU's fragmentation and immigration considerably. Both of these issues are also related with Turkey. In many instances when Turkey's accession to the EU has been securitized, the country was represented as a threat either in terms of a possible flow of Turkish immigrants to the EU, or in terms of its culture which is seen as "different" from the European culture ${ }^{60}$. Thus, for some Europeans, the way to stop the Turkish threat is keeping it out of the EU. Turkey has also securitized Europe, mainly because of its Sévres syndrome. It is largely the distrust of the West that directs Turkey to a search for closer ties with the Western world and especially the EU. This might seem paradoxical at first. However, when one reads this as part of the country's defensive Westernization, he/she can argue that Turkey chooses to become an EU member to avoid threats that it perceives from Europe. This, in a sense, is similar to the security logic behind European integration, which later turned out to be a desecuritization process.

While stating these differences between Turkish and EU security cultures, one should also be aware that the EU and its Member States also have such differences. Just like in the case of Turkey, for example, the military is perceived as "the 'carrier' of national identity" and "a symbol of national virtues" in the Polish security culture (Terlikowski et.al, 2013). An important feature of Turkey's security culture, an emphasis on territorial/national defence, is also observed in the cases of Greece (Economides, 2013: 155) and Finland (Seppo and Forsberg, 2013: 113). Similarly, Turkey's geopolitical/geostrategic approach can also be observed in some EU Member States such as the Czech Republic, mainly due to its fear of "geopolitical exposure" (Jireš, 2013: 70). The fear of geopolitical exposure is also embedded in Polish security culture (cf. Terlikowski, 2013). A distrust of Western powers usually accompanies such fears of geopolitical exposure, especially in the cases of the Czech Republic and Turkey. These similarities between EU Member States and Turkey may surely be proliferated. However, it suffices here to argue that Turkey's security culture is not very different from the national security cultures of EU Member States.

On the other hand, a crucial similarity between Turkey and the EU is their approach to multilateralism. This is also the case with all EU Member States. All of them support multilateral ways in tackling global and regional challenges and conflicts. This has been the most important factor in EU integration and in European security so far. The EU has an emphasis on effective multilateralism and emphasises its commitments to the UN charter and the Helsinki Final Act in all its

${ }^{60}$ See for example, Turkish Daily News (2002). 
Treaties. Turkey, on the other hand, as part of its Westernization efforts is not only an active member of international security organisations, but it also contributes to international crisis-management operations, from peace-making to post-conflict rehabilitation. Commitment to multilateralism is the most important common feature of the EU's, its Member States' and Turkey's security cultures.

One way to overcome the differences in Turkish and European security cultures might be to increase joint operations. Turkey's military experience in crisis management can contribute to the improvement of the EU's capabilities in terms of flexibility, mobility, sustainability, etc. In such terms, a convergence between Turkey and the EU would be to the benefit of both sides. Nevertheless, this military benefit is only one of the many aspects of security relations between Turkey and the EU, and, should not be over-emphasised. Furthermore, cooperation in this realm is currently not an option. This is mainly because of the stalemate in NATO-EU cooperation and problems with Turkey's involvement in the CSDP ${ }^{61}$.

A holistic approach to European security would certainly require the involvement of all its actors and finding common solutions to the complex problems of the EU's neighbourhood. Turkey as a prospective EU member and a long-standing ally in the West cannot and should not be left out of any European defence arrangements. A solution to the problems in Ukraine cannot be found without Turkey's involvement, for example. Furthermore, Turkey's uniquely unilateral stance in the case of Syria has revealed that excluding Turkey from Europe would cause its isolation and trigger an unprecedented tendency for unilateralism, which has not been a feature of Turkey's security culture before ${ }^{62}$. Such unilateralism could result in the detriment not only of Turkey itself and the EU but also of global security.

The indivisibility of security has shown itself recently in the case of Syrian civil war with the challenges of ISIS terrorism and the mass refugee flows to Turkey and Europe. These problems cannot be solved by individual European security actors. They need to be tackled through a holistic approach to security. All in all, it can be contended that despite their differences over the conception and perception of security, the security dynamics of Turkey and Europe have not only been

\footnotetext{
${ }^{61}$ With regard to this issue, it should be recalled that in almost every EU official text on its Member States' defence commitments, it is stated that NATO remains the foundation of their collective defence and any arrangement under the CSDP should not prejudice these commitments. Nonetheless, some EU Member States, especially France, display significant reluctance with regard to further development of NATO-EU cooperation, and, Turkey's involvement in the CSDP. One cannot separate the issue of NATO-EU cooperation (including respecting the Berlin-Plus Arrangements, and, Turkey's involvement in the CSDP) from the EU Member States' NATO commitments.

${ }^{62}$ It should be noted that there are some analysts who claim that its intervention in Cyprus and its policy on the Aegean can also be considered as unilateralist acts.(cf. Baran and Lesser, 2009: 204)
} 
interlinked but also interwoven for centuries. Neither their security cultures, nor their future can be separated from each other.

\section{Conclusion}

Divergences of Turkish and EU security cultures had considerably - and, in many instances, negatively - affected the relations between Turkey and the EU. Nevertheless, these divergences are not very different from those between the EU and its Member States. Its attitude on Turkey's accession will be a litmus test for the EU which will demonstrate whether it is actually that normative collectivity that it claims to be. On the other hand, if it still aims to become an EU member, Turkey also has to change its recent policy of over-securitization, which severely limits fundamental rights and freedoms in the country.

The EU's choice with regard to Turkey's membership will inevitably be about either drawing new lines across Europe on identity/religious lines or adopting a holistic approach based on de-securitization on the same lines. This paper has claimed that both sides securitize each other, and, while Turkey attempts to become an EU member to overcome the threat that it perceives from Europe, the EU has so far kept the country outside as a result of its threat perceptions. Desecuritization, the major practice that marked European integration, seems to be the only way for both sides to overcome their problems. The recent developments both in Europe and in their shared neighbourhood have revealed that only a holistic approach to European security can help solve the problems that the EU and Turkey face in their relations and in the world. Only if such a holistic approach can be put into practice then can the EU's "understanding" that "security is indivisible" mean more than just being three words nicely put together in a speech.

\section{References:}

Adler, E. (1997), "Seizing the Middle Ground: Constructivism in World Politics", European Journal of International Relations, Vol. 3, No.3, pp. 319-363.

Alecu de Flers, N. and Regelsberger, E. (2005), 'The EU and Inter-regional Cooperation', in International Relations and the European Union, eds. Christopher Hill and Michael Smith, Oxford: Oxford University Press, 2005, pp. 317-42.

Altınay, A.G. (2002) "Ordu-millet miti ve askerlik" (The myth of army-nation and conscription), Birikim, 160-161, pp. 61-62.

Altınay, Ayşe Gül and Tanıl Bora (2002) "Ordu, Militarizm ve Milliyetçilik” (The Military, Miltarism and Nationalism), in Tanıl Bora (ed.), Milliyetçilik: Modern Türkiye'de Siyasi Düşünce - Cilt 4 (Nationalism: Political Thought in Modern Turkey - Vol. 4), Istanbul: Iletişim Yayınları, pp. 140-154.

Aras, B. (2012), "Turkey's Mediation and Friends of Mediation Initiative", SAM Papers, no.4. http://sam.gov.tr/wp-content/uploads/2012/12/SAM_Papers_No.4-Dec12.pdf (20.10.2013). 
Aras, B. and Karakaya Polat, R. (2008), "From Conflict to Cooperation: Desecuritization of Turkey's Relations with Syria and Iran”, Security Dialogue, Vol. 39, No. 5, pp. 495-515.

Aydın Düzgit, S. and Keyman, F. (2014), "Democracy Support in Turkey’s Foreign Policy”, Carnegie Endowment for International Peace, March 25, 2014, http://carnegieendowment.org/2014/03/25/democracy-support-in-turkey-s-foreignpolicy (30 April 2014).

Aydınl, E. and Waxman, D. (2001) “A Dream Become Nightmare? Turkey's Entry into the European Union”, Current History, Vol. 100, No. 649, pp. 381-388.

Baran, Z. and Lesser, I.O. (2009), “Turkey's Identity and Strategy: A Game of ThreeDimensional Chess", in M. Schiffer and D. Shorr (ed.s), Powers and Principles: International Leadership in a Shrinking World, Lanham: Lexington Books, pp. 197-223.

Barroso, J.M.D. (2009), "Leading by Example: The EU and Global Governance", Conference on Global Governance, Brussels, 12 May 2009, (SPEECH/09/239 12/05/2009), http://europa.eu/rapid/pressReleasesAction.do?reference=SPEECH/09/239, (24 September 2011).

Biava, A., Drent, M., and Herd, G.P. (2011), “Characterizing the European Union's Strategic Culture: An Analytical Framework", Journal of Common Market Studies, Vol. 49, No. 6, pp. 1227-1248.

Bilgin, P. (2005), "Turkey's changing security discourses: The Challenge of Globalisation", European Journal of Political Research, Vol. 44, pp. 175-201.

Bilgin, P. (2010), "Clash of Security Cultures? Differences between Turkey and the European Union Revisited”, in Armağan Emre Çakır (ed.), Fifty Years of EU-Turkey Relations, London: Routledge, pp. 67-82.

Black, I. (2002), "Turkey must be kept out of the Union, Giscard says - Ankara backers condemned as "enemies of integration", The Guardian, 09.11.2002.

Buzan, B. (1991), People, States and Fear: An Agenda for International Security Studies in the Post-Cold War Period, Brighton: Harvester Wheatsheaf - Second Edition.

Buzan, B. (2000), “'Change and Insecurity' Reconsidered”, in Stuart Croft and Terry Terriff (ed.s), Critical Reflections on Security and Change, London, Portland: Frank Cass, pp. 1-17.

Buzan, B. and Diez, T. (1999), "The European Union and Turkey”, Survival, Vol. 41, No. 1, pp. 41-57.

Buzan, B. and Waever, O. (2003), Regions and Powers, Cambridge: Cambridge University Press.

Buzan, B., Waever, O. and de Wilde, J. (1998) Security: A New Framework for Analysis, Boulder and London: Lynne Rienner Publishers, Inc.

Castle, S. (2002), "Giscard Predicts 'end of EU' if Turkey joins", The Independent, 09.11.2002.

Cebeci, M. (2004), "The Multidimensional Security Concept and its Implications for PostCold War Europe and Turkey”, Unpublished PhD Thesis, Istanbul: Marmara University, European Union Institute. 
Cebeci, M. (2011), "NATO-EU Cooperation and Turkey", Turkish Policy Quarterly, Vol. 10, No. 3, pp. 93-103. $<$ http://www.turkishpolicy.com/dosyalar/files/Munevver\%20Cebeci(1).pdfs

Cebeci, M. (2012) "European Foreign Policy Research Reconsidered: Constructing an 'Ideal Power' Europe Through Theory?", Millennium - Journal of International Studies, Vol. 40 , No. 3, pp. 563-583.

Cizre, Ü. (2000), "Politics and Military in Turkey into the Twenty-first Century", EUI Working Paper, No. 2000/24, Florence: Robert Schuman Centre.

Cizre, Ü. (2003), "Demythologizing the National Security Concept: The Case of Turkey", The Middle East Journal, Vol. 57, No. 2, pp. 213-229.

Council of the European Union (2008), "Report on the Implementation of the European Security Strategy - Providing Security in a Changing World", S407/08 Brussels, 11 December 2008,

$<$ http://www.consilium.europa.eu/uedocs/cms_data/docs/pressdata/en/reports/104630.pd $f>(2$ Jan. 2009).

Council of the European Union (2010), "Internal Security Strategy for the European Union: 'Towards a European Security Model'", March 2010, Brussels, http://www.consilium.europa.eu/en/workarea/downloadasset.aspx?id=1083 (31 January 2011)

Davidson, J.W. (2013), "France, Britain and the intervention in Libya: an integrated analysis", Cambridge Review of International Affairs, Vol.26, No. 2, pp. 310-329.

Delcourt, B. and Remacle, E. (2009), "Global Governance: A Challenge for Common Foreign and Security Policy and European Security and Defence Policy", in Mario Telo, The European Union and Global Governance, Oxon and New York: Routledge, pp. 233-257.

Diez, T. (2005), "Constructing the Self and Changing Others: Reconsidering "Normative Power Europe"”, Millennium: Journal of International Studies, Vol. 33, No.3, pp. 61336.

Duchêne, F. (1972), "Europe's role in World Peace", in Richard Mayne (ed.), Europe Tomorrow, London: Fontana, 1972, pp. 32-47.

Duke, S. (2002), "CESDP and the EU response to 11 September: Identifying the Weakest Link", European Foreign Affairs Review, Vol. 7, No. 2, pp. 153-169.

Eckert, D. (2011), "EU Soldiers Accused of Torturing Civilians in Congo", DW-World.de Deutsche Welle, 29 March 2008. Available at: http://www.dwworld.de/dw/article/0,,3223692,00.html (accessed 1 October 2011).

Economides, S. (2013), "Greece", in H. Biehl, B.Giegerich, A. Jonas. (eds.), Strategic Cultures in Europe, Potsdam, Germany: Schriftenreihe des Zentrums für Militärgeschichte und Sozialwissenschaften der Bundeswehr, Springer Fachmedien Wiesbaden, pp.153-164.

Edwards, G. (2006), "Is There a Security Culture in the Enlarged European Union?", The International Spectator, Vol. 41, No. 3, pp. 7-23. 
European Commission (1999), "Speech by Günter Verheugen, Member of the European Commission: 'Enlargement: Speed and Quality' at the conference 'The Second Decade towards a New and Integrated Europe'”, SPEECH/99/151, Den Haag, 4 November 1999, europa.eu/rapid/press-release_SPEECH-99-151_en.doc

European Commission (2002a), "Council Common Position of 28 October 2002 updating Common Position 2001/931/CFSP on the application of specific measures to combat terrorism and repealing Common Position 2002/462/CFSP”, Official Journal, L 295 , 30/10/2002 P. $0001 \quad$ - 0004, <http://eur-lex.europa.eu/legalcontent/EN/TXT/?uri=CELEX:32002E0847>, (30 September 2013).

European Commission (2002b), 'Candidate Countries Eurobarometer 2001', March 2002, http://ec.europa.eu/public_opinion/archives/cceb/2001/cceb20011_en.pdf (30 September 2013).

European Commission and High Representative of the European Union for Foreign Affairs and Security Policy (2011) 'A New Response to a Changing Neighbourhood - A Review of European Neighbourhood Policy,' COM(2011) 303 final, Brussels, 25 May 2011.

Fisher Onar, N. and Nicolaïdis, K. (2013), "The Decentring Agenda: Europe as a postcolonial power", Cooperation and Conflict, Vol. 48, No. 2, pp. 283-303.

Grabbe, H. (2014), "Six Lessons of Enlargement Ten Years On: The EU's Transformative Power in Retrospect and Prospect", Journal of Common Market Studies, Vol. 52, No. S1, pp. 40-56.

Haine, J.Y. (2004), “An Historical Perspective”, in Nicole Gnesotto (ed), EU Security and Defence Policy - The First Five Years (1999-2004), Paris: EU Institute for Security Studies, pp. 35-53.

Haine, J.Y. (2005), "Back to Transatlantic Pragmatism", The International Spectator, Vol.40, No. 2, pp. 41-52.

Headline Goal 2010 (2004), approved by General Affairs and External Relations Council on 17 May 2004 endorsed by the European Council of 17 and 18 June 2004, https://www.consilium.europa.eu/uedocs/cmsUpload/2010\%20Headline\%20Goal.pdf

Heisbourg, F. (2009), "Conclusion - The unbearable weight of not being”, in Thierry Tardy (ed.), European Security in a Global Context - Internal and External Dynamics, London and New York: Routledge, pp. 211-217.

Hill, C. and Smith, K. (ed.s), (2000), European Foreign Policy - Key Documents, (London and New York: Routledge).

Howorth, J. (2007) Security and Defence Policy in the European Union, New York: Palgrave Macmillan.

Hürriyet (2000), “Ecevit: Türkiye’de Türk Silahlı Kuvvetleri’nin özel bir konumu var; bize bu bakımdan Avrupa ülkeleri örnek olabilecek konumda degil" (The TAF has a special position in Turkey; in this respect, European countries are not in a position to constitute an example for us), 15.01.2000. 
Hürriyet (2005) “Afganistan'a NATO Şemsiyesi” (NATO Umbrella for Afghanistan), 15.11.2005, accessed through: http://hurarsiv.hurriyet.com.tr/goster/ShowNew.aspx?id=3522027 on 20.08.2011.

Hürriyet (2014) "Davutoğlu'ndan Önemli Açıklamalar" (Important Statements by Davutoğlu), 7 August 2014. http://www.hurriyet.com.tr/dunya/26960210.asp (7 August 2014).

Hürriyet Daily News (2014) 'Turkey's telecom body given more power to monitor internet users', 9 September 2014, http://www.hurriyetdailynews.com/turkeys-telecom-bodygiven-more-power-to-monitor-internetusers.aspx?pageID $=238 \& n I D=71480 \&$ NewsCatID $=338$ ( 3 October 2014)

Jepperson, R.L., Wendt, A. and Katzenstein, P.J. (1996), "Norms, Identity, Culture and National Security", in Peter J. Katzenstein (ed.), The Culture of National Security: Norms and Identity in World Politics, New York: Columbia University Press, pp. 33-75.

Jireš, J. (2013), "Czech Republic” in H. Biehl, B.Giegerich, A. Jonas. (eds.), Strategic Cultures in Europe, Potsdam, Germany: Schriftenreihe des Zentrums für Militärgeschichte und Sozialwissenschaften der Bundeswehr, Springer Fachmedien Wiesbaden, pp.69-83.

Kadir Has University (2013), "KHas 2012 Türkiye Sosyal-Siyasal Eğilimler Araştırması Sonuçları Açıklandı", http://www.khas.edu.tr/news/799.

Karaosmanoğlu, A. (2000), "The Evolution of the National Security Culture and the Military in Turkey”, Journal of International Affairs, Vol. 54, No. 1, pp. 199-216.

Karaosmanoğlu, A. (2009), "Turkish Security Culture: Evolutionary or Carved in Stone”, in Peter M.E. Volten (ed.), Perceptions and Misperceptions in the EU and Turkey Stumbling blocks on the road to accession, Harmonie Paper 23, The Centre of European Security Studies (CESS), Groningen, pp. 27-46.

Katzenstein, P.J. (1996) "Introduction", in Peter J. Katzenstein (ed.), The Culture of National Security: Norms and Identity in World Politics, New York: Columbia University Press, pp. 1-32.

Manners, I. (2002), 'Normative Power Europe: A Contradiction in Terms?', Journal of Common Market Studies, Vol. 40, No. 2, pp. 235-258.

Manners, I. (2006), "Normative power Europe reconsidered: beyond the crossroads," Journal of European Public Policy, Vol. 13, No. 2, pp. 182-199.

Manners, I. (2008), "The normative ethics of the European Union", International Affairs, Vol. 84, no. 1, pp. 65-80.

Margaras, V. (2010), "Common Security and Defence Policy and the Lisbon Treaty Fudge: No common strategic culture, no major progress", EPIN Working Paper 28, June 2010. Available at SSRN: http://ssrn.com/abstract=1624802

Merlingen, M. (2007), "Everything is Dangerous: A Critique of "Normative Power Europe'," Security Dialogue, Vol. 38, No. 4, pp. 435-453.

Merlingen, M. and Ostrauskaité, R. (2006), European Union Peace Building and Policing, Oxon and New York: Routledge. 
Milliyet (2000), “Ordu'dan son dakika golü!”, (Last minute goal by the army!), 08.12.2000.

Moustakis, F. and Sheehan, M. (2002), "Democratic Peace and the European Security Community: The Paradox of Greece and Turkey", Mediterranean Quarterly, Vol. 13, No.1, pp. 69-85.

OECD (2014), “Official Development Assistance”, https://data.oecd.org/oda/net-oda.htm (10 September 2014).

Öniş, Z. (2011), "Multiple Faces of the 'New' Turkish Foreign Policy: Underlying Dynamics and a Critique", Insight Turkey, Vol. 13, No.1, pp. 47-65.

Özcan, G. (2002) "Türk Dış Politikasında Oluşum Süreci ve Askeri Yapı” (The Making Process of Turkish Foreign Policy and the Military Structure", in Barry Rubin and Kemal Kirişçi (ed.s), Günümüzde Türk DışPolitikası (Foreign Policy of Turkey Today), (Istanbul: Boğaziçi University Press), pp. 19-62.

Presidency Report on Strengthening the Common European Policy on Security and Defence (1999), adopted by the European Council, Cologne, 3-4 June, 1999.

Quille, G. (2009), "The Lisbon Treaty and its implications for CFSP/CSDP", Policy Briefing 2009, European Parliament, Directorate General for External Policies of the Union, $\quad$ DG EXPO/B/PolDep/Note/2009_169. http://www.europarl.europa.eu/meetdocs/2009_2014/documents/afet/dv/201/201009/20 100928lisbontreaty_cfsp-csdp_en.pdf (10 May 2010).

Republic of Turkey, Ministry of Foreign Affairs (2011a), "Turkey's Security Perspective, Historical and Conceptual Background, Turkey's contributions", accessed through: http://www.mfa.gov.tr/i_-turkey_s-security-perspective_-historical-and-conceptualbackground_turkey_s-contributions.en.mfa on 20.08.2011.

Republic of Turkey, Ministry of Foreign Affairs (2011b), "Regional Initiatives and Operations", accessed through: http://www.mfa.gov.tr/v_--regional-initiatives-andoperations.en.mfa on 20.08.2011.

Ruffa, C. (2011), "With or Without You? A Comparison of EU, European and US policies in Afghanistan", in Münevver Cebeci (ed.) Issues in EU and US Foreign Policy, Lanham, MA: Lexington Books, pp. 85-105.

Schröder, G. (2011), "The Future of Europe and the Transatlantic Partnership - Speech by Gerhard Schröder in the German Historical Institute Washington”, 10 May 2011 http://gerhard-schroeder.de/en/2011/05/10/washington-bucerius/

Solana, J. (2002), "Speech at the Annual Conference of the EU-ISS", Paris, 1 July 2002, http://www.iss.europa.eu/uploads/media/speech4.pdf (accessed on 20.08.2011).

Solana, J. (2003), "A Secure Europe in a Better World - European Security Strategy." Brussels, 12 December 2003, http://ue.eu.int/uedocs/cmsUpload/78367.pdf (12.04.2009)

Şardan, T. (2003) "Trafik Terörü İç Tehdit Oldu” (Traffic Terror has become an Internal Threat), Milliyet, 29.08.2003.

Tank, P. (2013), "Ideas and Change in Foreign Policy Instruments: Soft Power and the Case of the Turkish International Cooperation and Development Agency", Foreign Policy Analysis, published online ahead of print, 15 August 2013, doi: 10.1111/fpa.12031. 
Tardy, T. (2009), "Introduction", in Thierry Tardy (ed.), European Security in a Global Context - Internal and External Dynamics, London and New York: Routledge, pp. 1-13.

Terlikowski, M. (2013), "Poland", in H. Biehl, B.Giegerich, A. Jonas. (eds.), Strategic Cultures in Europe, Potsdam, Germany: Schriftenreihe des Zentrums für Militärgeschichte und Sozialwissenschaften der Bundeswehr, Springer Fachmedien Wiesbaden, pp. 269-280.

Terlikowski, M., Madej, M., and Górka-Winter, B. (2013), "Poland: indirect and ad hoc", in A. Leander (ed.), "Commercialising Security in Europe Political consequences for peace operations", Oxon and New York: Routledge, pp. 79-99.

Terriff, T., Croft, S., James, L., and Morgan, P.M. (1999), Security Studies Today, Cambridge: Polity Press.

Tofte, S. (2003) "NATO, ESDP and the role of the non-EU European Allies in the emerging European security order", Norsk Forum for Europa forskning Papers, accessed through: http://www.arena.uio.no/ecsa/papers/SunnivaTofte.pdf (15 April 2004).

Tol, G. (2013), “Erdogan's Syria Frustrations”, Foreign Policy, September 26, http://foreignpolicy.com/2013/09/26/erdogans-syria-frustrations/ (3 January 2014).

Turkish Daily News (2002), "Giscard remarks cause uproar in Ankara, Brussels", 02.11.2002.

Ulfstein, G. and Christiansen, H.F. (2013). "The Legality of the NATO Bombing in Libya”, International and Comparative Law Quarterly, Vol. 62, No. 1, pp. 159-171.

US Department of Defence (2003), "Secretary Rumsfeld Briefs at Foreign Press Center." News Transcript, 22 January 2003, $<$ http://www.defense.gov/Transcripts/Transcript.aspx?TranscriptID=1330> November 2009).

Waever, O. (1995), "Securitization and Desecuritization", in R.D. Lipshutz (ed.) On Security, New York: Columbia University Press, pp. 46-86.

Waever, O. (1998a), "Integration as security - Constructing a Europe at Peace", in Charles A. Kupchan (ed), Atlantic Security - Contending Visions, (New York: Council of Foreign Relations), pp. 45-63.

Waever, O. (1998b), "Insecurity, security, and asecurity in the West European non-war community" in E. Adler and M. Barnett (ed.s), Security Communities, Cambridge: Cambridge University Press, pp. 69-118.

Waever, O. (2000), "The EU as a security actor - Reflections from a pessimistic constructivist on post-sovereign security orders", in M. Kelstrup and M. Williams (ed.s), International Relations Theory and the Politics of European Integration - Power, Security and Community, (London: Routledge, 2000) pp. 250-294.

Whitman, R. (2006), "Roadmap for a Route March? (De-)civilianizing through the EU's Security Strategy", European Foreign Affairs Review, Vol. 11, No.1, pp. 1-15.

Zwolski, K. (2012), "The EU and a holistic security approach after Lisbon: competing norms and the power of the dominant discourse", Journal of European Public Policy, Vol. 19, No.7, pp. 988-1005. 